thunderstorms as explained in Prof. Silvanus Thompson's "Elementary Lessons," and similar elementary treatises :-

"The coal scence of small drops to form large ones, though it increases the electrical clensity on the surfaces of the drops does not increase the total quantity of electricity, and therefore cannot directly influcnce the olserved polential."

Surely this entirely omits the fact that the capacity of a sphere is equal to its radius, and thus in the case of eight equal spheres coralescing into one (which is taken by Prof. Thompson), not merely woukd the rensity be cloubled, but the potential of the same quantity woukl be increased four times.

In the well-known case given by Prof. 'Tait for the formation of a raindrop the potential of the same quantity might be increased fifty million times.

The source of the energy which is the cause of the increased potential in this case, is probibly the molecular force of cohesion released during the act of condensation and union, the cohesion and the electricity being oppositely placed, so that while the former is running down hill (as it were) the latter is obliged to run up; the top of the hill answering to the critical moment for di-ruptive discharge.

In view of these facts, it seems to me that if the above sentence is not altogether erroneous, it is certainly ambiguous, and liable to hreed false notions in the mind of the unreflecting and too credulous student. E. Douglas Arcinibald.

\section{Transparency of the Atmosphere.}

I'r may be, I think, desirable to correct an error which has crept into all the accounts of the extraordinary transparency of the atmosphere observed here last week. It occurred on Sunday, the Sth, and not on Monday, the $9^{\text {th }}$ inst. I can confirm the several cletails as to the cbjects visible to the unas-isted eye. But in one respect this effect was surpassed on August 20, 1887 when the cloutie flash of the Dunkirk light, distant from this place about forty-five miles, was visible for several hours. This light could not be seen here on the 8th inst.

Pavilion Ilotel, Follie.tone, July 16.

\section{J. Parnell.}

\section{Preserving the Colour of Flowers.}

Ix response to the inquiry of "A. W.," perhaps you will allow me to say that many years ago I met with Mdile. d'Angeville, the first lady to ascend Mont Blanc. She possessed the largest and best prescrved collection of Alpine flowers I have ever seen, and she assured me she never used anything but cotton-wool in her prese, changing it, of course, frequently. Her gentians, pedicularias, and other delicate plants were perfect in colour ; and having tried her plan myself, although with less care, and therefore with less success, I still have Alpine flowers which have retained their colour for twenty years.
54 Doughty street, July i 7 .
A. W. BUCKLAND,

Distribution of Animals and Plants by Ocean Currents.

IN connection with Miss Buckland's letter on this subject it may be interesting 10 note that, during a visit to Orotava, Teneriffe, in April 1887 (about the time mentioned by your correscondent), I obsirved and gathered a quantity of pumice-stone upon the seashore, the high tide mark being literally strewed with it. It secmed probable that it had been deposited there some weets or possibly months previously, as, had there been any quantity floating about in the sea, I should have noticed it, being engaged at the time tow-netting in the neighbourhoor and in the adjacent Cimary Islands. There was no evidence of vegetable debris having accompanied the pumice, nor did I notice any pirces with barnacles attached.

[,iverpoo!, July I 3 .

IsAaC C. THOMPSON.

\section{A Curious Resemblance}

Writst walking by the sea on the cliffs last Sunday, I perceivcd at a distance of about 1500 yards a flight of nearly forty ducks, travelliner at a good pace 2 or 3 feet above the level of the water. To me they appeared exactly what the so-called "sea-serpent" would, eight or ten of the birds flying close together and foming the head, whilst the rest trailed behind and formed the body and tail. At intervals they disappeared. This was causerl, I think, by the birds changing their course and flying either directly away or towards me; the former, I believe, in my case.

Some time afterwards I saw two other flights, and these resembled the first exactly, those with me also being surprised at their "snake"-like appearance. W. J. LockYER.

Thanet, July 16.

\section{The "Sky-coloured Clouds."}

THERE was a very bright display of these clouds last night. I could not perceive anything of them up to ro p.m., though the sky was clear, but by ro.18 they had become con picuous, and were brightest, so far as I observed, near miclnight.

I have seen very little account in any English paper of the visibility of these clouds beyond England, nor do I know whether they have been seen elsewhere than in Northern Europe. Has there been anything published on these points in English?

Neither have I seen any reference to the extensive observations of Herr O. Jesse at Steglitz, with his suggestions to observers. He considers it very important that this unusually favourable opportunity should be utilized for learning the motions of currents at great heights in the atmosphere. $\mathrm{He}$ suggests that photographs taken sim:iltaneously from two places at a distance of say 20 kilometres would be useful for ascertain. ing the height of the clouds ; but for this purpose the necessity arises of being able to calculate very accurately the azimuths and altitudes of different point: in the photograph. Their height can likewise be determined, though less accurately, by observations of the limit of sunshine upon them. II another way also, viz. by throwing an intense beam of electric light on the clouds; but I should cloubt the practicability of this.

The direction and rate of motion could be best made out, he says, by the use of a cloud-mirror. The changes that take place in the forms of the clourls before they have moved far make it difficult to ascertain their motion accurately.

Herr Jesse further thinks the intensity of the light of the clouds in different positions should be determined; also that the sky should be examined in the day-time with a polariscope and photometer in the hope that the presence of the matter of the clouds, then invisible to the eye, might be revealed.

Sunderland, July 13 .

T. W. BACKHOUSE.

\section{An Unusual Rainbow.}

STMGULARLy enough $\mathrm{I}$ can record the appearance of a rain. bow after sunset similar to that described by Mr. S. A. Hill (NATURE, March I5, vol. xxxvii., p. 464). I was not aware there was anything unusual in it until I read Mr. Andrew's com. munication, or would have written to you about it. I do not remember on what day I saw the rainbow, but it was about the date of that observed by Mr. Andrew. I called my wife's at tention to it, and attributed it to the briliant glow of the sunset tints. It had a secondary bow, and Mont Kogie as a dark background.

British Consulate, Noumea, May I5. L. L. LAYARD.

\section{TIMBER, AND SO.ME OF ITS DISEASES.}

IX.

I $F$ the leaves are stripped from a timber-trce early in the summer, or during their young conditions in the spring, the layer of wood produced in the current year-and probably even that formed next year-will be poor and thin. This is simply a fact of observation, and cloes not depend on what agent deprives the tree of its leaves. Those oaks which suffered so greatly from the ravages of certain tiny caterpillars this last summer (I 887) - many of them having all their leaves eaten away before July -will have recordecl the disaster by a thin annual ring of wood: it is true the more vigorous trees produced (at the expense of what stores of food materials remained over) a second crop of leaves in August, and so no doubt the zone of wood will prove to be a thin double one, but it is at the expense of next year's buds. 
Now there are very many foes which injure the leaves of our timber-trees, and I wish to show, as clearly as possible in a short article, how it comes about that injury to the leaves means injury to the timber. The sum total of the matter is that the substances which are to be sent down to the cambium, and converted through its agency into wood, are produced in the cells of the leaves: consequently, from our point of view, when an insect or a fungus consumes the substance of the leaves, it consumes timber in prospective. Similarly, when the leaves are removed from a tree by any agent whatever, the latter is robbed in advance of timber. A leaf, generally speaking, is an extended, flattened portion of a branch, covered by a continuation of the epidermis of the branch, and containing a continuation of its other tissues-the vascular bundles of the branch being continued as the venation, and the cellular cortex reappearing as the green soft tissue of the leaf. The epidermis of the leaf is so pierced at hundreds or thousands of nearly equi-distant points, that gases can enter into or escape from all its tissues : at these points are the so-called stomata, each stoma being a little apparatus which can open and close according to circumstances.

These openings lead into excavations or passages between the loose cells of the softer leaf-tissue, and if we supposed a very minute creeping organism to enter one of the stomata, it would find itself in a labyrinth of intercellular passages: supposing it able to traverse these, it could pass from any part of the leaf to any other between the cells; or it could emerge again from the leaf at thousands of places - other stomata. In traversing the whole of the labyrinth, however, it would pass over many millions of times its own length Moreover it would find these intercellular passages filled with a varying atmosphere of diffusing gases-oxygen, nitrogen, the vapour of water, and carbon-dioxide being the chief. It would also find the cell-walls which bound the passages damp, with water continuous with the water in the cells. If we suppose our hypothetical traveller threading the mazes of these passages at night, and able to perceive the changes which go on, it would find relatively little oxygen and relatively much carbon-dioxide in the damp atmosphere in the passages; whereas in the daylight, if the sun was shining brightly on the leaves, it would find the atmosphere rarer, and relatively little carbon-dioxide present, but an abundance of oxygen. These gases and vapour would be slowly moving in and out at the stomata by diffusion, the evaporation of the watery vapour especially being quicker on a dry, hot, sunny day.

Inside the cells between which these tortuous passages run, are contained structures which have much to do with these changes. Each of the cells I am considering contains a lining of protoplasm, in which a nucleus, and a number of small protoplasmic granules, coloured green, and called chlorophyll corpuscles, are embedded : all these are bathed in a watery cell-sap.

Now, putting together in a general manner some of the chief facts which we know about this apparatus, it may be said that the liquid sap inside the cells gives off water to replace that which escapes through the damp cell-walls, and evaporates into the above-named passages and out through the stomata, or at the surface. 'This evaporation of the water is in itself the cause of a flow of more water from betind, and this flow takes place from the vascular bundles forming the so-called venation of the leaf, coming directly from the wood of the stem. The course of this water, then, is from the soil. through the roots, up the young wood and into the venation of the leaf, and thence it is drawn into the cells we are considering. But this water is not pure water : it contains in solution small quantities of salts of lime, potash, magnesia, nitric, sulphuric, and phosphoric acids, as well as a little common salt, and traces of one or two other things. It is, in fact, of the nature of ordinary drinking-water, which always contains minute quantities of such salts: like drinking-water, it also contains gases (oxygen, nitrogen, carbon-dioxide) dissolved in it

It follows from what has be nn said that the cell-sap tends to accumulate small increasing quantities of these salts, \&c., as the water passes away by evaporation. But we must remember that the living contents--the protoplasm, nucleus, and the green chlorophyll-corpuscles-use up many of these salts for their life-purposes, and other portions pass into the cell-walls.

It will thus be seen that the green chlorophyll-corpuscles are bathed by a fluid cell-sap, the dissolved gaseous and mineral contents of which are continually changing, even apart from the alterations which the life-processes of the living contents of the cell themselves entail. We may say that the chlorophyll-corpuscles find at their disposal in the cell-sap, with which they are more or less in direct contact, traces of salts, oxygen, carbon-dioxide, and of course water, consisting of hydrogen and oxygen.

Now we have the best possible reasons for knowing that some such changes as the following occur in these chlorophyll-corpuscles, provided they are exposed to sunlight: they take up carbon-dioxide and water, and traces of minerals, and by means of a molecular mechanism which is as yet unexplained in actail, they perform the astonishing feat-for it represents an astonishing transformation when regarded chemically and physically-of tearing asunder, by the aid of the light, the carbon, hydrogen, and oxygen of the carbon-dioxide and water, and rearranging these elements in part so as to form a much more complex body-starch, or an allied compound, oxygen being at the same time set free.

It is of course not part of my present task to trace these physiological processes in detail, or to bring forward the experimental evidence on which our knowledge of them is based. It must suffice to state that these compounds, starch and allied substances, do not remain in the chlorophyll-corpuscles, but become dissolved and carried away through certain channels in the vascular bundles of the venation, and thence pass to wherever they are to be employed as food. The chemical form in which these substances pass from one cell to another in solution is chiefly that of grape-sugar, and it is a comparatively easy observation to make that the cells so often referred to contain such sugar in their sap.

We are only concerned at present with the fate of a portion--but a very large portion-of this starch and sugar: we can trace them down the vascular bundles of the venation, through the leaf-stalk, into the cortex, and eventually to the cambium-cells; and it is necessary to be quite clear on the following points: (I) the cambium-cells, like all other living cells which contain no chlorophyll, need to be supplied with such foods as sugar, starch, \&c., or they starve and perish; (2) since these foods are prepared, as we have seen, in the leaves, and in the leaves only, it is obvious that the vigour and well-being of the cambium depend on the functional activity of the leaves.

We have already seen how the cambium cells give rise to the young wood, and thus it will be clear how the formation of timber is dependent on the functional activity of the leaves. Moreover, it ought to be mentioned, by the way at least, that it is not only the cambium which depends upon the leaves for its supplies - all the roots, young buds, flowers, and fruits, \&c., as well as the cortex and cork-forming tissues, are competitors for the food supply. Now it is clear that if we starve the buds there will be fewer leaves develo sed in the following year, and so next year's cambium will again suffer, and so on

I have by no means traced all the details of even the first ramifications of the complex network of correlations implied by this competition of the various organs and tissues for the food supplies from the leaves; but probably the following proposition will be generally clear:- If the 
leaves are stripped, the cambium suffers starvation to a greater or less extent, depending on the intensity of its competition with other tissues, \&c. ; of course a starved cambium will form less wood, and, it may be added, the timber will be poorer.

Again, cven if the leaves are not stripped quickly from the tree, but the effect of some external agent is to shorten their period of activity; or to occupy space, on or in them, and so diminish the amount of leaf-surface exposed to the light and air ; or to block up their stomata, the points of egress and ingress for gases and water; or to steal the contents of the cells--contents which should normally be passed on for the growth, \&c., of other parts of the tree-in all or any of these ways injury to the timber may accrue from the action of the agent in question. Now there are numbers of parasitic fungi which do all these things, and when they obtain a hold on pure plantations or forests, they may do immense injury before their presence is detected by anyone not familiar with their appearance and life-histories.

The great difficulty to the practical forester who attempts to deal with these "leaf diseases" is at least twofold; for not only are the leaves so numerous and so out of reach that he can scarcely entertain the idea of doing anything directly to them, but (and this is by no means so clearly apprehended as it should be) they stay on the tree but a short time as a rule, and when they fall are a continual source of re-infection, because the spores of the fungi are developed on them. It is a curious fact that those fungi which are known to affect the leaves of foresttrees nearly all belong to two highly-developed groupsthe Uredinee and the Ascomycetes-and the remarkable biological adaptations which these parasites exhibit for attacking or entering the leaves, passing through periods of danger, and so on, are almost as various as they are numerous. Some of them, such as the Erysiphece or mildews on beeches, oaks, birches, ashes, \&c., only form small external patches on the leaves, and do little if any harm where the leaf-crown is large and active; others, such as many of the very numerous Spheriacece and their allies, which form small dark-coloured flecks and spots on leaves, may also be looked upon as taking only a slight tax from the leaves. Even in these cases, however, when the diseases become epidemic in certain wet seasons, considerable damage may accrue, because two chief causes (and many minor ones) are co-operating to favour the fungus in the struggle for existence: in the first place, a continuously wet summer means loss of sunlight and diminished transpiration, \&c., to the leaves, and so they form smaller quantities of food materials; and secondly, the damp in the atmosphere and leaves favours the fungi, and so they destroy and occupy larger areas of leaf surface.

It should be mentioned here, by the way, that all leaves of all trees are apt to have fungi on them in a wet summer, but many of these are only spreading their mycelia in all directions wer the epidermis, in preparation, as it were, for the fall of the leaf: they are saprophytes which feed on the dead fillen leaves, but camnot enter into them while yet alive. In some cases, however, this preparation for the fall is strikingly suggestive of adaptation towards becoming parasites. I will quote one instance only in illustration of this. On the leaves of certain trees in Ceylon, there was always to be found in the rainy season the much-branched mycelium of a minute Sphceria: this formed enormous numbers of branches, which, on the older leaves, were found to stop short over the stomata, and to form eventually a four-celled spore-like body just blocking up each stoma on which it rested. So long as the leaf remained living on the tree, nothing further occurred; but wherever a part of the leaf clied, or when the leaf fell moribund on the ground, these spore-like bodies at once began to send hyphie into the dying tissue, and thus obtained an early place in the struggle for existence among the saprophytes which finished the destruction of the cells and tissues of the leaf.

There is another group of fungi, the Capnodiece, which form sooty black patches on the leaves, and which are very apt to increase to a dangerous extent on leaves in damp shady situations: these have no connection with the well-known black patches of Rhytisma from which the leaves of our maples are rarely free. This last fungus is a true parasite, its mycelium penetrates into the leaf tissues, and forms large black patches, in and near which the cells of the leaf either live for the benefit of the fungus alone, or entirely succumb to its ravages: after the leaf has fallen, the fungus forms its spores. Nevertheless, although we have gone a step further in destructiveness, foresters deny that much harm is done to the trees-no doubt because the foliage of the maples is so very abundant. Willows, pines, and firs suffer from allied forms of fungi.

But it is among the group of the Uredinece or rusts that we find the most extraordinary cases of parasitism, and since some of these exhibit the most highly developed and complex adaptations known to us, I propose to select one of them as the type of these so-called "leaf diseases." This form is Coleosporium Senecionis (Peridermium Pini), rendered classical by the researches of several excellent botanists.

It is true, Coleosporium Senecionis is not in some respects the most dangerous of these fungi-or, rather, it has not hitherto been found to be so-but in view of the acknowledged fact that foresters have not as yet been able to devise practical measures against the ravages of these numerous rust-fungi, and since we are as yet very ignorant of the details of the biology of most of them, it seems advisable to choose for illustration a form which shows in a distinct manner the complexities of the subject, so that those interested may see in wh.t directions biologists may look for new results. That the story of this fungus is both complicated and of great biological interest will be sufficiently evident from the mere recital of what we know concerning it.

\section{(To be continued.)}

H. Marshall Ward.

\section{MICHELL'S PROBLEM.}

FOR the last two hundred years the attention of logicians and mathematicians has been directed to the inverse principles of the theory of probability, in which we reason from known events to possible causes. 'Two different methods of calculation are in use, which give approximately the same results. According to the celebrated theorem of James Bernoulli, "If a sufficiently large number of trials is malle, the ratio of the favourable to the unfavourable events will not differ from the ratio of their respective probabilities beyond a certain limit in excess or defect, and the probability of keeping within these limits, however small, can be made as near certainty as we please by taking a sufficiently large number of trials." "The inverse use of this theorem is much more important and much more liable to objection and difficulties than the direct use. In the words of De Morgan, "When an event has happened, and may have happened in two or three different ways, that way which is most likely to bring about the event, is most likely to have been the cause."

The second principle, due to Bayes, is thus given by De Morgan, "Knowing the probability of a compound event, and that of one of its components, we find the probability of the other by dividing the first by the second."

These principles have been accepted by the great majority of thinkers, and freely used by Laplace, Poisson, Herschel, and De Morgan. Stanley Jevons ("Principles of Science") gives a luminous account of the value of the 